Acta vet. scand. 1988, 29, 239-243.

From the Department of Obstetrics and Gynaecology,

College of Veterinary Medicine, Hautjärvi, Finland.

\title{
Relationship between Rectal Findings of Corpus Luteum and Whole Milk Progesterone Levels in Postpartum Dairy Cows
}

\author{
By K. Heinonen
}

\begin{abstract}
Heinonen, K.: Relationship between rectal findings of corpus luteum and whole milk progesterone levels in postpartum dairy cows. Acta vet. scand. 1988, 29, 239-243. - The reliability of clinical ovarian findings was assessed as an indicator of luteal function in primiparous dairy cows. The postpartum period of 103 cows following their first parturition was studied by thrice weekly rectal palpation of ovaries and whole milk progesterone assay from 1 week after parturition to the first insemination. The relationship between milk progesterone levels and 1101 ovarian findings was compared during the follicular phases, short luteal phases and during the early, mid and late thirds of normal luteal phases. The compatibility between elevated progesterone and palpable corpus luteum was $71 \%$, and between low progesterone and lack of corpus luteum $77 \%$. In $10 \%$ of all rectal examinations the finding was unspecified; i.e the clinician could not differentiate between luteal and follicular activity. During the acyclic period prior to the initiation of luteal function, the proportion of false corpus luteum findings was $11 \%$. The corpora lutea of the short oestrous cycles were more difficult to palpate than those of normal cycles. During early dioestrus the corpus luteum was significantly more difficult to palpate than during the rest of dioestrus. The percentage of unspecified findings was highest during early dioestrus.

The paper discusses the reliability of rectal examination as a method of diagnosing cyclicity and of evaluating the responsiveness of a cow to prostaglandin treatment.
\end{abstract}

rectal examination; short cycles.

\section{Introduction}

In field practice, differentation between noncycling (true anoestrus) and cycling (silent oestrus) cows is based on the presence or absence of a rectally palpable corpus luteum.

The average interval from calving to first ovulation determined by elevation of progesterone levels is reported to vary between 17 and 30 days in dairy cows (King et al. 1976, Webb et al. 1980, Fonseca et al. 1983, Larsson et al. 1984b). The first luteal phase is often shorter than subsequent phases (Morrow et al. 1969, Fonseca et al. 1983, Larsson et al. 1984b).
A finding of functional corpus luteum (CL) in connection with a normal, nonpregnant uterus is generally accepted as an indicator of cyclicity. The compatibility between a rectal finding of a functional CL and elevated milk progesterone levels has been reported to vary between 70 and $86 \%$ (Boyd \& Munro 1979, Watson \& Munro 1980, Larsson et al. 1984a). The presence of a functional $\mathrm{CL}$ is a prerequisite for successful treatment with prostaglandin F2 $\alpha$ or its analogues (PG). During the first 6-8 days of the cycle (day $1=$ oestrus) the sensitivity of a CL is either absent or reduced (Momont \& Sequin 1984, Watts \& Fuquay 1985), 
probably due to the relative lack of cells having PG receptors (Fitz et al. 1981, Fitz \& Sawyer 1982). Rectal findings during the first third of dioestrous (period of reduced sensitivity to PG) seem not to be comparable with those during the rest of dioestrus, nor the rectal findings during short luteal phases.

Watson \& Munro (1980) found a $69 \%$ agreement between negative rectal palpation findings of $\mathrm{CL}$ and low progesterone levels in a study in which the majority of animals were cycling. One source of false CL findings could have been palpation of the regressed CL from the previous cycle. Higher compatibility between low progesterone levels and absence of a CL could therefore be expected during the acyclic period following parturition, during which no regressed CL is likely to be present.

The objectives of the present study were to assess the reliability of a single rectal CL finding as an indicator of cyclicity and to investigate rectal findings during short luteal phases and during various parts of luteal phases of normal length.

\section{Material and methods}

The management of the herd, clinical examinations and progesterone assays are described in detail by Heinonen et al. (1988). A total of 103 heifers belonging to an experimental farm and having calved for the first time between April and August 1981 were included in the study. The ani- mals were of 3 different breeds: 42 Ayrshires, 42 Friesians and 19 Finncattle.

All animals were clinically examined at 2-3 day intervals starting 1 week after parturition and ending at the first insemination. The animals were inseminated at the first detected oestrus after 60 days post partum. The clinician conducting the rectal examinations was unaware of the previous findings. All examinations were carried out by the same clinician.

Ovarian findings were classified into 4 groups:

1. corpus luteum $(C L)=$ smooth structure, protruding from the surface of the ovary; uniform liverlike consistency and well defined borders,

2. follicle $(F)=$ follicle $\geq 1 \mathrm{~cm}$ in diameter, no CL in either ovary,

3. undefined activity (A) = prominent, smooth formation with poorly defined borders and too thickly walled to be regarded as a follicle; clinician could not differentiate between luteal and follicular activity,

4. no function $(N)$ = no palpable function, either follicles or CL.

Milk progesterone levels of $\geq 8 \mathrm{nmol} / 1$ were considered indicative of luteal activity. Luteal phases were divided into 2 groups: short phases with 1 to 4 subsequent elevated progesterone levels (cycle length $<18$ days) and normal luteal phases with 5 or more subsequently elevated progesterone levels (cycle length $\geq 18$ days).

The relationship between clinical findings and

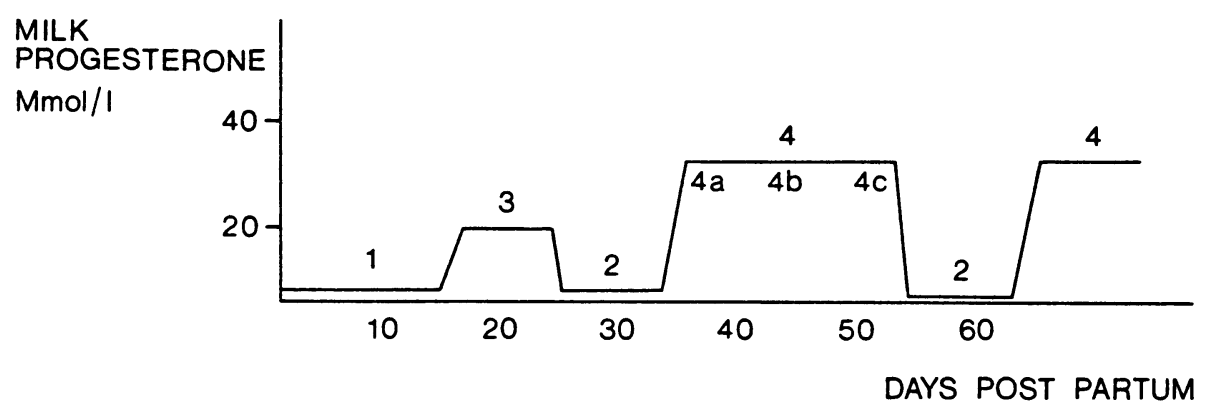

Figure 1. Schematic representation of the different phases of post partum studied when detecting the accuracy of rectal corpum luteums diagnosis. 
progesterone levels were studied during 4 phases of the postpartum period (Fig. 1):

1. acyclic period from calving to the first elevation of milk progesterone,

2. follicular phase(s) between subsequent luteal phases,

3. short luteal phase(s),

4 normal luteral phase:

a. first 5 days of elevated progesterone

b. mid dioestrus

c. last 5 days of elevated progesterone.

The chi-square test and t-test were used for statistical evaluation of the data.

\section{Results}

The first palpable follicle was detected $16.8 \pm 0.7$ (mean \pm standard error of mean) days post partum. The first increase in milk progesterone occurred $26.3 \pm 1.4$ days post partum. The short luteal phases occurred most frequently at the onset of cyclicity: The first luteal phase was short in $77.7 \%$ of the animals and the second luteal phase in only $10.1 \%$ of the animals $(p<0.01)$. The mean peak progesterone level was $22.4 \pm 1.2 \mathrm{nmol} / 1$ during the first luteal phase and $61.2 \pm 1.4 \mathrm{nmol} / 1$ during the second $(p<0.01)$.

A total of 1101 rectal findings were related to milk progesterone levels. In the entire material the agreement between rectal findings and milk progesterone levels was $71 \%$ with high progesterone and $77 \%$ with low progesterone. Ten per cent of all

Table 1. Rectal palpation findings in relation to milk progesterone levels in 103 heifers.

\begin{tabular}{lccccc}
\hline Milk pro- & $\begin{array}{c}\text { No. of obser- } \\
\text { vations }\end{array}$ & \multicolumn{5}{c}{ \% of findings } \\
\cline { 3 - 6 } & CL & F & N & \multicolumn{1}{c}{ A } \\
\hline$<8 \mathrm{nmol} / 1$ & 610 & 13 & 46 & 31 & 10 \\
$\geq 8 \mathrm{nmol} / 1$ & 491 & 71 & 15 & 5 & 9 \\
\hline
\end{tabular}

Level of

significance

*** *** *** N.S.

$\mathrm{CL}=$ corpus luteum, $\mathrm{F}=$ follicle, $\mathrm{N}=$ no function, $\mathrm{A}=$ unspecified activity.

${ }^{* * *} \mathrm{p}<0.001$ with the chi-square test

N.S. $p>0.05$. rectal findings were deemed unspecified. The percentages of different findings are shown in Table 1.

Table 2. Rectal palpation findings during the low progesterone period ( $<8 \mathrm{nmol} / \mathrm{l}$ ) before the first elevation in milk progesterone (phase 1) and during the low progesterone periods between subsequent dioestrus (phase 2) in 103 postparturient heifers.

\begin{tabular}{lccccr}
\hline \multirow{2}{*}{ Phase no. } & $\begin{array}{c}\text { No. of obser- } \\
\text { vations }\end{array}$ & CL & F & N & A \\
\cline { 3 - 6 } 1 & 423 & 11 & 47 & 31 & 11 \\
2 & 187 & 17 & 45 & 30 & 8 \\
\hline Level of & & & & & \\
significance & & $*$ & N.S. & N.S. & N.S. \\
\hline
\end{tabular}

$\mathrm{CL}=$ corpus luteum, $\mathrm{F}=$ follicle, $\mathrm{N}=$ no function, $\mathrm{A}=$ unspecified activity.

${ }^{*} p<0.05$ with the chi-square test N.S. $p>0.05$.

Table 3. Rectal palpation findings during short and normal (see text) dioestrus in 103 postparturient heifers.

\begin{tabular}{lccccr}
\hline Type of & No. of obser- & \multicolumn{4}{c}{ \% of findings } \\
\cline { 3 - 6 } dioestrus & vations & CL & F & N & A \\
\hline Short & 146 & 64 & 19 & 7 & 10 \\
Normal & 345 & 74 & 13 & 4 & 9 \\
\hline
\end{tabular}

Level of

significance

* N.S. N.S. N.S.

$\mathrm{CL}=$ corpus luteum, $\mathrm{F}=$ follicle, $\mathrm{N}=$ no function, $A=$ unspecified activity.

${ }^{*} p<0.05$ with the chi-square test N.S. $p>0.05$.

Table 4. Rectal palpation findings during early dioestrus (first 5 days of elevated progesterone), mid and late dioestrus (last 5 days of elevated milk progesterone) in 103 postparturient heifers.

\begin{tabular}{lccccc}
\hline \multirow{2}{*}{$\begin{array}{l}\text { Stage of } \\
\text { dioestrus }\end{array}$} & $\begin{array}{c}\text { No. of obser- } \\
\text { vations }\end{array}$ & \multicolumn{5}{c}{ \% of findings } \\
\hline Early & 115 & $64^{\mathrm{a}}$ & $14^{\mathrm{a}}$ & $5^{\mathrm{a}}$ & $17^{\mathrm{c}}$ \\
Mid & 152 & $77^{\mathrm{b}}$ & $13^{\mathrm{a}}$ & $4^{\mathrm{a}}$ & $6^{\mathrm{d}}$ \\
Late & 78 & $81^{\mathrm{b}}$ & $10^{\mathrm{a}}$ & $6^{\mathrm{a}}$ & $3^{\mathrm{d}}$ \\
\hline
\end{tabular}

$\mathrm{CL}=$ corpus luteum, $\mathrm{F}=$ follicle, $\mathrm{N}=$ no function, A $=$ unspecified activity.

$a, b, c, d:$ percentages within variable groups with different superscripts differ. $a-b p<0.05, \quad c-d p<0.01$ with the chi-square test. 
Findings from the acyclic period before the first elevation in milk progesterone and from the follicular phases between subsequent luteal phases are presented in Table 2 .

Findings from the short and normal luteal phases are presented in Table 3.

Findings from the early, mid and late thirds of the normal luteal phases are presented in Table 4.

\section{Discussion}

In the entire material the compatibility between elevated progesterone levels and rectal findings of functional $C L$ was $71 \%$. This is slightly lower than that of earlier reports in which the percentage varied between 70 and 86 (Boyd \& Munro 1979, Watson \& Munro 1980, Larsson et al. 1984a). Variation in expertise is probably one of the reasons for these differences. Other possible explanations are the higher proportion of rectal examinations carried out during the short luteal phases in the present study compared with other studies in which the examinations were conducted less frequently (Larsson et al. 1984a) or later post partum (Boyd \& Munro 1979, Watson \& Munro 1980). The CL of the short phases, occurring mostly in the early post partum period, was detectable in only $64 \%$ of examinations.

During the acyclic period before initiation of luteal function, $11 \%$ of the examinations gave false CL findings (with consequent false cyclicity diagnosis); during the follicular phases between 2 luteal phases the proportion of false findings was $17 \%$. The difference probably originates from the difficulty in differentiating between a functional and regressing CL. False CL findings that result in an erroneous diagnosis of early or late luteal phase may lead to useless PG treatment, although the diagnosis of cyclicity was correct.

Rectal findings from the early third of the luteal phase (period of reduced sensitivity to $P G$ ) were similar to those of the short luteal phases; only $64 \%$ of the $C L$ were detectable and the proportion of unspecified findings (A) was high. In fact the short luteal phases that occur before initiation of normal luteal function are beginnings of a normal luteal phase which is interrupted by early release of PG F2 $\alpha$ (Manns et al. 1983, Duby et al. 1985). Peters et al. (1977) reported a $70 \%$ oestrous response to PG treatment among cows with palpable CL, while Tanabe \& Hann (1984) found a $91 \%$ response when cows in early dioestrus were excluded; the treatment was given 7 or more days after the preceding oestrus. This indicates that there may be animals in early dioestrus with a palpable CL before they are responsive to PG treatment.

In the present study $77 \%$ and $81 \%$ of CLs of the mid and late luteal phase respectively were detectable by rectal palpation. The remainder (roughly $20 \%$ ) were cases in which the $C L$ was not palpable but would most likely have responded to PG treatment.

On the basis of the present data it can be concluded that a rectally palpable corpus luteum is a relatively reliable indication of elevated milk progesterone levels and cyclicity. A single rectal examination during normal, and particularly during short, luteal phases with no other information as to the stage of the cycle is an unreliable method of determining the stage of the cycle and the consequent responsiveness of the cow to PG F $2 \alpha$ treatment.

\section{References}

Boyd H, Munro CD: Progesterone assays and rectal palpation in pre-service management of a dairy herd. Vet. Rec. 1979, 104, 341-343.

Duby RT, Browning T, Carey D, Black DL: Progesterone synthesis and histology of postpartum bovine corpora lutea. Theriogenology 1985, 23, 619-627.

Fitz TA, Sawyer HR, Niswender GD: Characterization of two steroidigenic cell types in the ovine corpus luteum. Biol. Reprod. 1981, 24, suppl. 1, 64.

Fitz TA, Sawyer HR: Changes in quantity and size of steroidogenic cells in ovine corpora lutea during the estrous cycle and early pregnancy. Biol. Reprod. 1982, 26, suppl. 1, 36.

Fonseca FA, Britt JH, McDaniel BT, Wilk JC, Rakes $A H$ : Reproductive traits of Holsteins and Jerseys. Effects of age, milk yield and clinical abnormalities 
on involution of cervix and uterus, ovulation, estrous cycles, detection of estrus, conception rate and days open. J. Dairy Sci. 1983, 66, 1128-1147.

Heinonen $K$, Tuovinen $V$, Savolainen $E$, Miettinen $P$, Alanko $M$ : Postpartum reproductive functions in Finnish Ayrshire and Friesian cows after three subsequent parturitions. Acta vet. scand. 1988, 29, preprint.

King GJ, Hurnik JF, Robertson HA: Ovarian function and estrus in dairy cows during early lactation. J. Anim. Sci. 1976, 42, 688-692.

Larsson K, Ahlin K-A, Garcia M, Edqvist L-E: Relationship between clinical ovarian findings and progesterone levels in postpartum dairy cows. Proc. 10th Int. Congr. on Anim. Repr. and AI, Illinois 1984a, vol. 3, p. 400.

Larsson K, Jansson L, Berglund B, Edqvist L-E, Kindahl $H$ : Postpartum reproductive performance in diary cows. I: Influence of animal, breed and parity. Acta vet. scand. 1984b, 25, 445-461.

Manns JG, Humphrey WD, Flood PF, Mapletoft RJ, Rawlings N, Cheng $K W$ : Endocrine profiles and functional characteristics of corpora lutea following onset of postpartum ovarian activity in beef cows. Canad. J. Anim. Sci. 1983, 63, 331-347.

Momont $\mathrm{HW}$, Seguin BE . Influence of day of estrus cycle on response to PG F $2 \alpha$ products: implications for AI programs for dairy cattle. Proc. 10th Int. Congr. on Anim. Repr. and AI, Illinois 1984, vol. 3, p. 335.

Morrow DA, Roberts SJ, McEntee K: Postpartum ovarian activity and involution of the uterus and cervix in dairy cattle. 1 . Ovarian activity. Cornell Vet. 1969, 59, 173-189.

Peters JB, Welch JW, Lauderdale JW, Inskeep EK: Synchronization of estrus in beef cattle with PG F2 $\alpha$ and estradiol benzoate. J. Anim. Sci. 1977, 45, 231235.

Tanabe TY, Hann RC: Synchronized estrus and subsequent conception in dairy heifers treated with prostaglandin $F 2 \alpha$. 1. Influence of stage of cycle at treatment. J. Anim. Sci. 1984, 58, 805-811.

Watts TL, Fuquay JW: Response and fertility of dairy heifers following injection with prostaglandin $F 2 \alpha$ during early, middle or late diestrus. Theriogenology 1985, 23, 655-661.

Watson ED, Munro CD: A re-assessment of the technique of rectal palpation of corpora lutea in cows. Brit. vet. J. 1980, 136, 555-560.

Webb R, Lamming GE, Haynes NB, Foxcroft GR: Plasma progesterone and gonadotrophin concentrations and ovarian activity in post-partum diary cows. J. Reprod. Fert. 1980, 59, 133-143.

\section{Sammenfatning}

Förhàllandet mellan rektala observationer av corpus luteum och progesteronnivàn $i$ helmjölk hos postpartuma mjölkkor.

Pålitligheten av kliniska ovariala observationer som indikatorer på luteal funktion hos mjölkkor värderades. 103 kors postpartuma period efter deras första kalvning undersöktes 3 gånger i veckan, med rektal palpation av ovarierna samt progesteronprov ur helmjölk från 1 vecka efter kalvning till den första inseminationen.

Förhållandet mellan progesteronnivån i mjölk och 1101 ovarieobservationer jämfördes under de follikulära faserna, korta luteala faserna samt under den tidiga, mittersta och sena tredjedelen av normala luteala faser. I $71 \%$ av fallen kunde corpus luteum palperas då progesteron halten var förhöjd, och i $77 \%$ av fallen sammanföll låg progesteronhalt med avsaknad av corpus luteum. I 10\% av de rektala undersökningarana var observationerna ospecifierade, med andra ord kunde klininkern inte skilja mellan luteal och follikulär aktivitet.

Under den acykliska perioden före början av den luteala funktionen var andelen felaktiga observationer av corpus luteum $11 \%$. Corpora lutea i de korta oeströsa cyklerna var svårare att palpera än de i normala cykler. Under tidig dioestrus var corpus luteum signifikant svårare att palpera än vid de övriga faserna av dioestrus. Under tidig dioestrus var andelen ospecifierade observationer störst. I artikeln diskuteras pålitligheten av rektal examination som en metod för att diagnostisera cyklicitet och för att bedöma en kos mottaglighet för prostaglandinbehandling.

\section{(Received December 10, 1987).}

Reprints may be requested from: Kalevi Heinonen, Department of Obstetrics and Gynaecology, College of Veterinary Medicine, SF-04840 Hautjärvi, Finland. 
